\title{
Promoting Bank Stability through Compen- sation Reform: Lessons from Iceland
}

\author{
Jay Cullen, Assistant Professor of Law, University of Sheffield School of \\ Law \\ Guðrún Johnsen, Assistant Professor of Finance, Faculty of Business Ad- \\ ministration, University of Iceland
}

\begin{abstract}
This article argues that the program of compensation reform at financial institutions - despite recent wide-ranging changes - remains incomplete. A considerable body of theoretical and empirical research has been developed which, for the most part, suggests that compensation incentives embedded in compensation contracts at banks encouraged risk-taking behaviour which contributed to the Global Financial Crisis. Extensive reforms to compensation rules at financial institutions have been implemented across the globe, including increased use of deferral, mandatory capping of bonuses and the introduction of claw-back powers. Relying on observations on the failures of Icelandic and UK banks, and legal and economic analyses of compensation reforms in each jurisdiction, this paper argues that some elements of the Icelandic and UK reform programs ought to be transposed to the EU level. Arguably, these recommendations will help improve the resilience of the European banking system and contribute to greater financial stability.
\end{abstract}

Keywords: Bankers pay; compensation; policy making; financial regulation; prudential regulation; financial crisis; special purpose vehicles; total-returnswaps.

JEL Classification: G28, K23

Icelandic Review of Politics and Administration Vol. 11, Issue 2 (333-354)

(C) 2015 Contacts: Jay Cullen, jay.cullen@sheffield.ac.uk; Guðrún Johnsen, gudrunj@hi.is

Article first published online December 17th 2015 on http://www.irpa.is

Publisher: Institute of Public Administration and Politics, Gimli, Sæmundargötu 1, 101 Reykjavík, Iceland

Stjórnmál \& stjórnsýsla 2. tbl. 11. árg. 2015 (333-354) Fræđigreinar

(C) 2015 Tengiliðir: Jay Cullen, jay.cullen@sheffield.ac.uk; Guðrún Johnsen, gudrunj@hi.is

Vefbirting 17. desember 2015 - Birtist á vefnum http://www.irpa.is

Útgefandi: Stofnun stjórnsýslufræđa og stjórnmála, Gimli, Sæmundargötu 1, 101 Reykjavík

DOI: http://dx.doi.org/10.13177/irpa.a.2015.11.2.11

This work is licensed under a Creative Commons Attribution 3.0 License. 


\section{Introduction}

In spite of the extensive structural and regulatory reforms on financial oversight in Europe, this article argues that the program of reform to executive compensation at banks in the EU remains incomplete. We argue that, in constructing further restrictions on bankers' incentives in the EU, regulators ought to pay regard to the reforms to compensation systems in both the UK and Iceland, two jurisdictions which suffered immense damage to their economies during the Global Financial Crisis (GFC). One of the key themes to emerge from the GFC was that excessive risk-taking by bankers and traders at financial institutions had been encouraged by incentives embedded in their compensation packages. It was not simply at senior levels that perverse compensation incentives were present; however, it has been the pay incentives of senior bankers that have been cited - arguably with much justification - for the risk-taking behavior which characterized the pre-GFC banking business. Whilst there are some differences in their focus, a large proportion of studies point to a strong relationship between executive compensation and excessive institutional risk-taking - characterized by both an increase in asset risk and in short-termist business strategies - as the adoption of excessive risk resulted in huge financial reward. Short-termism in these compensation contracts was manifested in several ways, but especially through the award of performance-based bonuses which prioritized return on equity (RoE) as a performance-measurement metric, and through the increased award of stock options at banks to managers, the use of which may encourage short-term strategic horizons.

On the basis of studies purporting to demonstrate a link between excessive risk and private incentives - and also perhaps with a nod to political sensibilities concerning the role of banks in causing the post-2008 global recession - there has been large-scale reform to the structure and composition of bankers' compensation incentives, with the general aim of reducing the capacity for bankers to profit individually from excessive risk-taking. These reforms are at various stages of implementation in developed Western financial centers, with some jurisdictions implementing much deeper reforms than others. This itself raises two of the main challenges facing regulators in this area: firstly, to create a level-playing field for employees of institutions which operate at the supranational or multi-jurisdictional level in what is now undoubtedly a global business sector; and secondly, to discourage a 'race-to-the-bottom' amongst regulatory jurisdictions hoping to attract banking business.

Moreover, we shall argue that the dangers posed by inappropriate incentives have arguably not been sufficiently marginalized by recent reforms to compensation in the EU, and we therefore believe that further reform will be necessary if the stability of the financial system is to be safeguarded. To build this case, we rely, firstly, on empirical work which focuses on the incentive problems which contributed to the Icelandic banking collapses. These collapses were (with Icelandic bank assets exceeding GDP by a factor of ten) by far the largest experienced during the GFC in relative terms, and the background stories of disastrous decision-making driven in many respects by poor incentives offer important lessons on both the causes of financial fragility and solutions to moder- 


\section{STJÓRNMÁL \& \\ STJÓRNSÝSLA}

ating the power of incentives to generate that fragility. We secondly analytically discuss research into compensation-related drivers of both UK and European bank failures, to demonstrate that the Icelandic experience was not an outlier, and that flawed incentives have the capacity to cause system-wide meltdown when operative at mega-banks, and may occur in jurisdictions supposedly characterized by regulatory sophistication and advanced risk management practices. This will also provide context for our later discussion of the reform of remuneration incentives at UK and Icelandic banks, the principles of which we posit ought to be incorporated into well-designed compensation system at the EU level.

Of course, the causes of the multiple banking failures in Iceland as well as in Europe and the US are neither simple nor clear cut. It is impossible to accord proportionate weighting to the many drivers of the crisis, which included macroeconomic imbalances, a well-documented savings glut, inappropriate monetary policies, a lack of financial oversight or cross-border surveillance, and misplaced faith in modern risk-management techniques, as well as poor micro- and macro- incentives. Whilst recognizing this plurality, we concentrate our analysis solely on incentive pay structures as a contributing factor to the banking collapses, and leave it to other scholars to account for alternative causes.

The article is organized as follows. In the following section, we survey some of the main literature on the topic of executive compensation incentives and risk-taking, including at banks. In Section 2, we undertake a brief case study examining the incentive problems which led to the Icelandic banking collapse and further contrast these findings with other research into the remuneration structures and executive behaviors at large UK and EU banks to draw parallels with the Icelandic experience. In Section 3 , we provide an overview of reforms to the composition of senior banker compensation packages in the UK and Iceland and contrast these efforts with the more limited measures thus far adopted in the EU. In Section 4, we make some recommendations for further reform to senior bankers' pay, in light of the empirical and theoretical findings presented earlier in the paper. Section 5 concludes.

\section{Literature}

A tremendous growth in research on executive pay in publicly-listed firms has been witnessed over the last two decades which has greatly increased our understanding of pay practices in listed companies. Much of this research does not, however, take into account the endogenous nature of compensation contracts, which are largely determined through bargaining power based-interactions between the CEO, the remuneration committee, and the board of directors, where CEO outside options, monitoring capacity of the board and compensation consultants may have significant impact. It also neglects the largely hidden design of compensation contracts of employees at marginally lower levels of organizations and how much impact those incentives may or may not have on their levels of production, even where those members are very senior (so-called ' $\mathrm{C}$-level staff'). Many important questions regarding the effects of incentive pay on behaviors of C-level staff and by implication on operational outcome, therefore remain unanswered, 
as the main problem with measuring the effects of compensation still remains that of identification. As a result, compensation arrangements are associated with a large number of observable and unobservable variables, derived from both firm and employee characteristics, making it difficult to interpret any observed correlation between executive pay and firm outcomes as evidence of a causal relationship (Frydman and Jenter 2010). This problem is particularly precarious in banks because of the difficulty in differentiating causality between individual decision-making and the overall economic climate.

Notwithstanding these observations, research on compensation in both banks and non-financial firms suggests that incentives such as stock options and earnings-based performance bonuses may increase risk in several ways. For example, there appears to be a link between incentive compensation and the manipulation of earnings and/or other benchmarks; for example, earnings-based bonus plans incentivize earnings management (Healy 1985; Holthausen et al. 1995) and firms manipulate the disclosure of information around CEO option awards, delaying the release of good news and accelerating the disclosure of bad news (Aboody \& Kasznik 2000; Yermack 1997). Equity-based incentives may encourage managers to continue to expend firm resources to manipulate the stock price upwards over the short-term (Peng \& Roell 2008) whilst there is positive relationship between introduction of higher proportions of equity incentives and subsequent increases in firm risk (Chen et al. 2006). A series of studies also document a positive correlation between CEOs' equity incentives and earnings manipulation (Cheng \& Warfield 2005; Bergstresser \& Philippon 2006; Burns \& Kedia 2006; Efendi et al. 2007; Johnson et al. 2009). Empirical research also confirms a link between litigation risk and compensation incentives: Talley and Johnsen (2005) and Roell and Peng (2008) each document a non-linear relationship between variable pay and litigation risk of the firm.

In the case of banks, the risks inherent in compensation contracts may lead to particularly destabilizing trends, due mainly to their high leverage, and the interaction between equity-based compensation awards and capital structure. Despite the so-called "debt-equity irrelevance proposition theorem" (Modigliani \& Miller 1958), in the presence of financial distortions such as tax differentiation, information asymmetries, bailout guarantees and agency costs, high leverage leads to greater firm instability. Axiomatically, leverage magnifies the effects of changes in trading positions and will lead to higher profits (or losses) relative to unleveraged positions in the event of price movements. On this basis, Minsky (1986) noted some time ago that managers at banks rewarded through stock options have strong incentives to expand the balance sheet of their institutions and increase leverage. Paradoxically, this state of affairs is not helped by the use of so-called managerial 'disciplining' devices, including stock options, takeover threats, or board monitoring of managerial performance, each of which increases the likelihood of higher leverage (Berger et al. 1997).

In the absence of any downside risk - for example, sanctions for failure or any deferral/claw-back mechanisms relating to compensation - bank management has strong incentives to increase leverage to chase profits, which may be especially strong where 
markets are exhibiting signs of over-exuberance and unsustainable rises in price levels (often referred to as 'bubbles'). There is a considerable body of research which demonstrates clear links between asset prices and the supply of credit (Borio \& Lowe 2002; Detken \& Smets 2004). There is also a strongly evidenced link between increases in risk-taking by banks and the various stages of the leverage cycle, during which banks' capital structures become less robust, thanks to investor (and banker) expectations of future price increases which appear to justify lower collateral demands (Bhattacharya et al 2011; Geanokoplos 2010). An indirect implication of this phenomenon - that increasing bank leverage may cause asset price inflation (Fostel \& Geanakoplos 2013) - is that leverage that drives an asset bubble also feeds into the size of stock-based compensation for bank executives (Cullen 2014). Research further demonstrates that bank compensation contracts encourage risk-taking to profit from speculative stock price rises, providing managerial incentives to increase the speculative component of stock prices to increase short-term returns (Bolton et al. 2005). On the basis of these findings, it is perhaps to be expected that the higher the stock-option wealth within financial firms the higher the bankruptcy risk of that firm (Armstrong \& Vashishtha 2012) and that asset writedowns during the GFC were more strongly related to asset volatility in highly leveraged financial institutions (Chesney et al. 2011). In contrast, in situations where top bankers receive a greater proportion of their remuneration in salary and bonuses rather than stock options, they are less likely to take high risks (Palia \& Porter 2004).

Whilst the executive compensation literature is rich in explaining the ways in which remuneration may encourage excessive risk taking, it lacks a clear explanation as to where the motivation to do so originates. Possible rationales may be found in contributions by Akerlof and Shiller (2015) and Akerlof and Romer (1993). Akerlof and Romer in particular show that incentives exist for firms to "go broke for profit at society's expense (to loot) instead of to go for broke (to gamble on success)." Where lax regulation and accounting practices or low individual penalties dominate, owners are granted an incentive to pay themselves more than their firms are worth and then default on their debt obligations. Of course, this implies that bankruptcy for profit is especially likely in the presence of government guarantees - either explicit or implicit - of financial institution liabilities. Under such circumstances bankruptcy for profit can easily become a more attractive strategy for owners of the firm rather than maximizing true economic value as it increases the extractable rents available. Other motivations to gamble at play beyond compensation incentives (especially in the banking sector) include extreme competition and tight margins, career concerns and shareholder risk aversion, each of which places limits on the effectiveness of compensation reforms in isolation to reduce excessive risk-taking (Avgouleas \& Cullen 2015).

In acknowledging these empirical challenges, it is necessary to take stock of cases where confidentiality has been lifted (the Icelandic case) or extensive corroborative evidence may be found to infer a relationship between compensation incentives and excessive risk (the UK and EU) to avoid building policy proposals only on empirical evidence that may be marked by identification problems between cause and effect. On this basis, we now turn to the case 
of the Icelandic bank collapses of 2008 and some parallels in the UK and European jurisdictions, which highlight how the design of compensation systems may contribute to weak capital structures (including manipulation) and excessive risk-taking.

\section{The failure of the Icelandic banks: a brief case study}

A rare opportunity to test the hypothesis that equity compensation incentives lead to excessive risks and misreporting arose in the case of failed financial institutions in Iceland following the GFC. Between 2000 and 2008, Iceland's banking system experienced exponential growth; in 2008 some 97\% of the system collapsed. Following this, the Icelandic Parliament established a Special Investigation Commission (SIC) to report on how Iceland's banking sector failed. Naturally, in a sector of such complexity, there were many obstacles in documenting a link between compensation and risk in the Icelandic system; yet, thanks to virtually unconstrained access to data, legal documents, and bankers' testimony, the evidence collected by the SIC indicates strongly that incentive pay - as well as psychological factors such as bounded rationality and groupthink - played a significant role. Moreover, as we shall outline, developments in the structure and scale of compensation at Icelandic banks closely mirrored trends at banks in other jurisdictions.

\subsection{Icelandic bank expansion}

Between 2003 and 2008, the assets of Iceland's three largest banks - Glitnir, Kaupthing Bank and Landsbanki - grew from 1,451 billion ISK to 14,437 billion ISK, thanks largely to four main developments: (i) an increase in the size and incidence of mergers and takeovers by Icelandic banks of foreign institutions; (ii) greater competition in retail lending, particularly for mortgages; (iii) higher volumes of lending to foreign parties, including intra-group and inter-group loans; and (iv) financial innovation, particularly the use of Icelandic bank securities in CDOs (Collateralized Debt Obligations) sold in US debt markets thanks to their high credit rating (SIC 2010 Chapter 21). Two main consequences flowed from these developments: first, Icelandic banks became much more dependent on borrowing in short-term debt markets to fund their assets; and second, Icelandic bank system leverage rose significantly.

In spite of this increased fragility, the average Icelandic bank RoE indicated extraordinary profitability; indeed, Icelandic bank reported RoE exceeded other Nordic institutions' average each year, often by wide margins. Reported book equity was also remarkably high, meaning that these high RoE figures were being delivered with relatively high capital ratios. The reported efficiency of Iceland's banks' investments was also remarkable; between 2003 and 2008, with the exception of 2007, Iceland's banks reported mean return on assets (RoA) of over double that of other Nordic banks, in spite of the higher cost of funds experienced by Iceland's banks thanks to their reliance on wholesale funding (Flannery 2010). 


\subsection{Capital manipulation and compensation incentives}

Upon investigation, it became clear that the high profitability and high capital figures were based upon large reporting and accounting manipulations. In the context of this article, there is strong evidence that the changes in behavior were driven by incentive-pay in the Icelandic banking sector and later on by a bet-for-resurrection philosophy. This manipulation was systemic: even prior to the privatization of the major banks in Iceland (which was only completed in 2000) instruments had been set up in relation to bankers' variable pay that had the effect of misreporting equity levels (SIC Volume 3, 2010, 60).

One of the main forms of capital manipulation found by the SIC was inappropriate hedging of option grants to staff, both in Landsbanki and Bundadarbanki (which later merged with Kaupthing), through off-shore special purpose vehicles (SPV), which were under the de facto control of the banks' management. In the case of Landsbanki, initially these SPVs were funded by Landsbanki itself. The SPVs, in return, went to the stock market to buy shares in Landsbanki, which consequently affected Landsbanki's share price, particularly as management exercised control over the timing of sales and purchases. A forward contract was set up between Landsbanki and the SPV to cover the funding costs of the SPV. The intent was that as the options vested, the SPV would sell Landsbanki its shares back at strike price, at no "extra cost" to the bank, since options would only be exercised in the event that the share price had risen, and the bank was now hedged against a rise in the share price. The fact that the bank was still exposed against its own downside risk was ignored, despite the fact that the SPV would never be able to repay the loan if the shares of Landsbanki fell in value, let alone if the bank became insolvent. The risk of the SPVs investment in the shares of Landsbanki therefore remained on the bank's balance sheet, even though their value ought to have been deducted from the equity base according to IFRS accounting standards. Axiomatically, the equity cushion in the case of these SPV holdings was non-existent in this regard. As funding conditions tightened in 2006, funding of these SPVs was moved from Landsbanki to rival banks, Glitnir, Kaupthing and Straumur. In return, Landsbanki issued a banker's guarantee against the default of the SPVs.

As Landsbanki collapsed, $13.4 \%$ of its shares in Landsbanki were held in eight different SPVs or trusts, which were set up with the same purpose of holding shares of Landsbanki to hedge employee call options in the bank (SIC Volume 3, 2010, 60-9). The eight SPVs combined were the second largest owner of Landsbanki shares and one of them, Empennage Ltd, was among the 20 largest owners in Landsbanki according to the Moody's Company Profile in June 2007. Landsbanki's former in-house counsel testified to the SIC that he was asked by management to collect proxies from the off-shore entities to cast a vote on the bank's remuneration policy at the annual general meeting in 2007, which awarded large compensation packages to top executives; he duly did so (SIC Volume 3, 2010, 68-9). Dubious accounting practices were also used to artificially increase revenues at Landsbanki. A third of the bank's 2008 half-year profits were due to a valuation between market terms of funding and funding terms of a loan portfolio 
comprising so-called total-return-swaps (TRS). At the time, the bank accounted for $\$ 56$ $\mathrm{mln}$ in revenue due to this mark-to-market funding difference, but refunded the TRS on June 30th at terms that would have left the bank with only $\$ 6 \mathrm{mln}$ in revenues for this item. There was no mention of this in the banks' accounts as required by IFRS accounting standards (SIC Volume 2, 2010, 65-7).

Similar practices were present in Glitnir and Kaupthing. Glitnir's employees had borrowed the equivalent amount of $17 \%$ of Glitnir's equity base to buy shares in the bank. The employees enjoyed exceptional funding terms, often better than the sovereign and the bank itself. No collateral was requested to back these loans, apart from the shares themselves (loan-to-value 100\%) and, at times, put options were issued by the bank, leaving staff virtually risk-free from market movements and repayment of the loan (SIC Volume 3, 2010, 33-9, 44-5). Kaupthing employees also received favorable lending terms and put options on the underlying shares in Kaupthing. Auditors of Kaupthing pointed out that IFRS standards demanded the equity base to be written down in line with put options issued. In response, Kaupthing management requested staff members to issue $10 \%$ personal guarantees against the loans, instead of staff receiving put options to hedge against drop in the shares, the underlying collateral. Again, no collateral (aside from the shares themselves) was requested. The board of Kaupthing passed a resolution to exempt staff members from the personal guarantee a week before the bank collapsed (SIC Volume 3, 2010, 78-83). Kaupthing staff members and management, who took part in the stock purchasing program were the owners of the shares, and received dividends accordingly.

There is also compelling evidence that options grants in Iceland's major banks were often supported not by true outside investment, but through funding from rival banks, with contracts and guarantees in place to ensure that the issuing bank in fact carried all the risk of its own equity. This 'cartel-like' behavior saw Icelandic banks agreeing to reciprocal funding arrangements simply in order to support their aggregate equity values. In the event, as credit conditions worsened considerably in 2008, when staff members tried to exercise their options as the options vested, management of the bank tried to influence staff not to exercise, issuing announcements stating that the exercise of these rights would be harmful for the bank. The exercise of options at this point became subject to management approval which was, unsurprisingly, invariably refused (SIC Volume 3, 2010, 61). However, thanks somewhat to the manipulation discussed, from 20042007, variable compensation as a share of total pay in the Icelandic banking sector grew immensely and in some cases from 35\% to 90\% for top 1\% earners (Johnsen 2014).

\subsection{Parallels with the UK \& EU}

The developments in compensation systems at Icelandic banks were symptomatic of changes in remuneration structures across global banking institutions, including in the EU and UK. The trend in increased executive compensation occurred largely in response to increased institutional size, as well as compensating executives for shareholder returns generated by higher leverage. Whilst the just-discussed mechanisms used in Ice- 


\section{STJÓRNSÝSLA}

land were somewhat different to those employed in EU and UK banks, which relied less on overt capital structure arbitrage and manipulation and more on the use of innovation in risk-weight management processes and opaque intermediation chains, the motives were synonymous: the desire to obtain capital relief to fund further investments, partially incentivized by prevailing compensation structures. Few cases have been brought to court in Europe as a result of the GFC; therefore, unlike in Iceland, there is a lack of availability of non-confidential information relating to bankers' responses to incentives. However, a cursory glance at capital levels and compensation size at both UK and EU banks may be used to infer similar developments as those which occurred at those in Iceland (for the sake of brevity, we confine the analysis to general trends across the jurisdictions mentioned).

Recent evidence from the UK for example suggests that compensation practices were causative of some reckless behavior leading up to the GFC; indicatively, the FSA in 2009 commented that "inappropriate incentive structures played a role in encouraging behavior which contributed to the financial crisis." The main culprit was arguably the strong focus placed on RoE as a performance-measurement metric, which became commonplace in the pre-GFC banking environment. As a focus on RoE incentivizes leverage, the dangers of RoE-based compensation plans become clear: "Individuals have incentives to be preoccupied with short-term leveraged growth rather than sustainability and good conduct" (UK Parliamentary Commission 2013).

Indeed, in the context of the incentive structures prevalent at the UK's largest banks the FSA (2011) made it clear that the incentives to focus on increasing revenue, profits, assets and leverage (rather than on capital, liquidity and asset quality) provided by explicit reference in incentives packages to measures such as operating profit, earnings per share growth and return on equity, were ubiquitous across the UK banking sector. Without any form of inbuilt malus or claw-back, axiomatically, "[s]uch a design of ... compensation provides executives with incentives to seek improvements in short-term earnings figures even at the cost of maintaining an excessively high risk of large losses down the road" (Bebchuk \& Fried 2010).

CEOs and other executives at UK banks were thereby incentivized partly by their compensation systems to chase shareholder returns: accordingly, RoE increased at large UK banks from 1\% in 1989, to 38\% by 2007 (Haldane 2012). However, as Haldane notes, "[V]irtually all of the increase in RoE of major banks [since 2000] appears to have been the result of higher leverage. Banks' return on assets - a more precise measure of their productivity - was flat or even falling over this period ... [Higher returns in this period are therefore] likely to have been an act of risk illusion." Naturally, this higher RoE fed into profits and therefore compensation plans. Yet, the widespread nature of these incentives and the capital structure fragility they induced resulted in a weakly capitalized UK banking system, despite the significant shareholder returns produced; there was a clear increase in leverage across the UK banking system in the lead-up to 2008 (World Bank 2009).

European-level banks engaged in similar practices. The De Larosiere Report (2009) 
to the European Commission concluded that: "Remuneration and incentive schemes within financial institutions contributed to excessive risk-taking by rewarding shortterm expansion of the volume of (risky) trades rather than the long-term profitability of investments... the structure of this remuneration, induce[d] too high risk-taking and encourage short-termism to the detriment of long-term performance." As with the UK, a good deal of this risk-taking comprised higher leverage - both on- and offbalance sheet, which increased markedly at European banks in the run-up to the GFC; in a survey of European bank leverage (ABN AMRO, Banco Santander, BNP Paribas, Commerzbank, Crédit Agricole, Credit Suisse, Deutsche Bank, Société Générale, UBS, and UniCredit $\mathrm{SpA}$ ), it was found that average leverage ratios (assets-to-capital multiple) increased from just over 20:1 in 2000 to over 32:1 in 2008 (World Bank 2009) Another study places average European bank leverage in 2008 at over 50:1 (Bologna et al 2014).

Naturally, these trends invite comparison with those at UK and Icelandic banks, and it is clear that similar capital relief techniques were employed in order to reduce capital requirements and free up balance sheets for further lending. At the Swiss bank UBS, for example, management increased significantly the securitization of mortgage assets, and at the same time, the bank began to retain a large proportion of these collateralized debt obligations (CDOs) on its balance sheet. Because these CDOs were rated highly (normally AAA), the bank did not have to find any additional capital to fund these assets. Moreover, this had profound consequences in the context of executive and trader compensation; bankers at UBS had serious incentives to grow the balance sheet as large as possible as, in the absence of capital charges, these securities delivered huge profits as banks earned pure alpha on these instruments, and thereby increased RoE. As executive bonuses at banks were determined by reference to their RoE, the size of bankers' compensation was linked directly to the size of its CDO positions. Similar practices were engaged in across EU banks (Clementi et al. 2009).

As noted in the introduction, we are not, of course, suggesting that these trends were driven entirely by compensation incentives, as the motives for operating with low capital levels extend to other drivers. Yet, there is no escaping the logic that - as in Iceland compensation systems in the EU and UK favored extremely short-term timeframes and did not adequately mitigate the risks of relying on weak capital even in the face of balance sheet expansion. When these incentives operate at a systemic-level, regulation of those incentives and proper calibration of their application becomes warranted.

\section{Recent reforms to compensation: EU, UK and Iceland}

In this section we briefly outline the progress of reform programs undertaken in the EU, UK, and Iceland in order to establish the current regulatory position with regard to bank executive compensation in each jurisdiction. In doing so, we highlight idiosyncratic features of the UK and Icelandic compensation regimes not currently reflect at the EU level, which we contend ought to be implemented on a pan-European basis. 


\section{STJÓRNMÁL \& \\ STJÓRNSÝSLA}

\subsection{EU reforms}

The Fourth Capital Requirements Directive (CRD IV) aimed "to implement international principles and standards at Union level by introducing an express obligation for credit institutions and investment firms to establish and maintain, for categories of staff whose professional activities have a material impact on the risk profile of credit institutions and investment firms, remuneration policies and practices that are consistent with effective risk management" (Directive 2013/36/EU, Para 62). The CRD IV compensation rules are wide-ranging and designed to catch all categories of staff that hold senior management positions or whose activities designate them a "material risk taker" (MRT). There were anticipated difficulties in defining the term "material risk-taker"; to this end, technical guidance was issued in December 2013 by the EBA to determine how to apply the term "material risk taker" to bank staff, and it is accordingly anticipated that, as a rule of thumb, only the very highest earners (the top $0.3 \%$ ) will be captured by the definition. In relation to MRTs, CRD IV contains prescriptive rules on the structure of their compensation. The basic principles are as follows:

(i) Limits to compensation as a proportion of capital - total variable remuneration should not limit the capacity of the financial institution concerned to strengthen its capital base;

(ii) Cap on variable compensation - There is a default position that variable compensation must be capped to the same level as fixed compensation (1:1), although with shareholder approval, a ratio of 1:2 will be permitted;

(iii) Bonus structure - Up to 25 per cent of the bonus may be paid in long term instruments valued on a discounted basis (which will result in a ratio of greater than 1:2). These instruments must be deferred for at least five years to be eligible for the discount;

(iv) Restriction and deferral of variable compensation - At least 50 per cent of the variable remuneration must consist of shares or equivalent instruments which reflect the credit quality of the institution as a going concern or which can be converted to equity in adverse circumstances. Moreover, at least 40 per cent of the variable remuneration must be deferred over a period of not less than three to five years. Where the variable remuneration component is of a particularly high amount, at least 60 per cent must be deferred; and

(v) Clawback of variable compensation - All bonus payments remain subject to malus and/or clawback, in certain circumstances, including where the staff member participated in or was responsible for conduct which resulted in significant losses to the institution, or, failed to meet appropriate standards of fitness and propriety. 


\subsection{UK reforms}

In addition to the provisions of CRD IV, the Bank of England has amended substantially changes made to the UK Remuneration Code ('Rem-Code') now issued jointly by the Financial Conduct Authority (FCA) and the Prudential Regulation Authority (PRA). For example, whilst the Rem-Code reflects CRD IV in mandating long-term performance-based pay, it stretches the period over which compensation awards may vest. So, the Rem-Code requires that a significant proportion of non-fixed compensation (at least 40 percent) be deferred over a period of five years for some relevant staff at financial institutions (PRA-designated risk managers with senior, managerial or supervisory roles) and to seven years for the most senior managers, with a further three years for senior managers whose firm is subject to a regulatory investigation (Bank of England 2015). In relation to the director of a firm which is particularly large, is organizationally complex and the nature, scope and complexity of its activities is significant, and the remuneration of that director is particularly high $(£, 500,000$ or more), the amount of variable pay that must be deferred rises to 60 percent (PRA, SYSC 19.A.3.49). These periods are significantly longer than those under CRD IV and, as we shall argue, are more appropriate to the banking cycle.

Under the Rem-Code, banks are also now required to consider alternative measures of performance to traditional metrics such as earnings per share (EPS) or total shareholder return (TSR), as these may encourage a short-term focus during the life of the compensation plan, yet expose institutions to longer-term risks (FCA SYSC 19A.3.23). Accordingly, in assessing a financial firm's performance for the purposes of the award of variable compensation to employees, remuneration committees must have regard principally for the institution's risk-adjusted profits, rather than its earnings (SYSC 19.A.3.22-19A.3.23; 19A.3.25).

\subsection{Icelandic reforms}

Under the European Free Trade Agreement (EFTA) Iceland is obliged to adopt all European Directives into Icelandic law, so much of the Icelandic reform program will eventually mirror progress at the European Community level (for example, CRD IV), albeit with special local amendments.

Direct changes have been made to the rules governing incentive pay at Icelandic financial institutions, and apply to banks, mutual funds and insurance companies. The Icelandic Parliamentary Law on Financial Undertakings, 2002, grants implementation powers to the FME which introduced reforms via regulatory instrument in June 2013. A major difference between the EC and Icelandic reform programs is that the main provisions of the FME regulations apply to all employees, not simply MRTs. Similarly, when adopting CRD IV in the spring of 2015, the Icelandic parliament used its residual power to implement even stricter policies on bankers' pay, via the legal code.

The main themes of the regulations on bankers' compensation implemented in Iceland are, as stipulated by law on financial undertaking no. 161/2002 with amendments no. 57/2015 and 75/2010 and regulation no. 700/2011: 
(i) Cap on variable pay - annual variable pay can be no more than $25 \%$ of total annual salary, and calculated without any bonus, although the use of any form of payment instrument is permitted;

(ii) Heightened oversight - Incentive schemes are subject to initial approval of the shareholders and the FME as well as any substantive subsequent changes to those schemes must be reported to and approved by the FME and shareholders. Three different assessments are submitted annually to the board and the FME by the risk management officer, the internal auditor and the compliance officer, respectively, of whether the incentive scheme meets regulatory objectives, internal rules, or whether it introduces excessive risk-taking, encourages illegal behaviour or attempts to circumvent rules and legislation. The three assessing officers and their staff are all exempt from the incentive scheme in place;

(iii) RoRWA obligatory performance metric - at least $15 \%$ of performance is to be measured by reference to Return on Risk Weighted Assets (RoRWA).

(iv) Constructive ambiguity - mandatory annual review of incentive schemes is stipulated by the regulations, in order that changes may be made to the schemes throughout the cycle to address such aspects as the market environment, strategic focus, and any emerging or imminent risks. This allows for a 'constructive ambiguity' in the design of incentive schemes to prevent bank employees from exploiting (or 'gaming') the system, as rules and targets may vary from one year to the next;

(v) Probibition on bonus pay at unprofitable banks - Should the bonus payment prevent the firm from turning a profit, or if it prevents the firm to strengthen its equity base by the requirement of the FME, no bonus payments should be paid out. Thus, in many ways, this is the intellectual twin of the Capital Conservation Buffer imposed on financial institutions under Basel III (BCBS 2010);

(vi) The Board of Directors at financial institutions are excluded from any type of incentive pay - members of the board of directors must be paid only in salary.

\section{Recommendations based upon the UK and Icelandic reform programs}

We argue that, whilst the post-GFC reforms to pay at the EU-level are welcome, they remain subject to certain weaknesses. On this basis, we suggest that future reform of EU-level compensation incentives ought to be based upon the additional safeguards put in place in the UK and Icelandic jurisdictions. In doing so, we do not hold the UK and Icelandic examples as paragons of perfection, and we shall also consider critiques from beyond the legislative and policymaking communities of existing compensation arrangements. As we acknowledge in the introduction, there is also a significant problem with establishing correlations between individual and overall corporate performance, and empirical studies are marked by measurement problems.

We favor direct reform for several reasons, but the most significant is that a considerable body of research suggests that corporate governance reform itself (in terms 
of altering structures or introducing new processes) cannot prevent excessive risk in the banking sector (Avgouleas \& Cullen 2014). In fact, there is scant evidence that corporate governance has weakened over the last 30 years; instead, most indicators show that governance has considerably strengthened over this period (Holmström \& Kaplan 2001, Hermalin 2005) and yet, the incidence of banking crises is increasing. Moreover, some studies since the GFC to show that banks with 'good' corporate governance and remuneration systems i.e. those in which shareholder and manager interests were most aligned, performed worse than other banks during the GFC, and suffered the most losses (Fahlenbrach \& Stulz 2011). We cannot therefore envisage that addressing any perceived flaws in the traditional approaches to corporate governance and pay-setting - such as strengthening shareholder rights and advocating more extensive use of 'performance-based pay' as conceived prior to the crisis - will offer constructive solutions to inform future reform.

\subsection{Increasing deferral periods}

As outlined above, deferral requirements are common in each of the jurisdictions we have examined, and reflect general industry practice. Under the so-called "informativeness principle" (Holmström 1979), the compensation of managers ought to be linked to a measure of performance which is as informative as possible about managerial effort. It is extremely difficult to assess performance in banking. One tiny mis-step - deliberate or not - in the valuation of assets and bootstrapping of yield curves to value, or investment in complex, illiquid financial assets and the adoption of large exposures, can translate into significant losses or significant gains for the firm as a whole, with very little change in reporting or the degree of manipulation required. On this basis, where longer-term measures are harder to manipulate and are more informative (as is the case in the banking industry), managers' pay should also be long-term, if it is to be efficient. Deferral of compensation goes some way to solving this problem by providing greater links between pay and performance, principally for two reasons: firstly, it dis-incentivizes the manipulation of earnings or excessive risk adoption by senior managers to capture short-term rewards, making it less attractive for bankers to target higher investment risk because the threat of default in the intervening deferral period may wipe out any equity-based gains in the intervening years before payout (Bhagat \& Romano 2009); and secondly, it allows for the effects of the financial cycle to be smoothed out, reducing the possibility that excessive compensation awards are captured on the basis of inflated asset prices or other direct manipulation. An additional benefit of deferral is, of course, that unvested discretionary pay does not attract proprietary rights until the vesting date, and upon the satisfaction of predetermined criteria. The threat of litigation in the case of bankers who leave employment voluntarily therefore ought not to be serious, providing certainty to both banks and their employees during compensation negotiations, and one would expect the pay market to adapt to these contingencies.

We argue that current recommended/mandatory deferral periods at the EU level (3-5 
years) are not substantial enough to prevent the adoption of excessive risk. On the basis of the empirical work surveyed here, and the considerable research undertaken into the duration of the financial cycle, the available evidence suggests that the length of deferral recommended by regulatory agencies, and the somewhat limited circumstances under which claw-back may operate, may not be sufficient to entirely capture the financial cycle 'window'. This implies that deferral requirements may not provide sufficient protection against the re-emergence of short-termism or, indeed, inappropriate incentive structures. In the EC and Icelandic jurisdictions, which have expressly legislated for this, the deferral period is a mere three-to-five years and only 40 percent of variable compensation must be deferred. In the context of credit cycles, which are naturally intertwined with the performance of banks and which may persist for a decade or more, three years does not seem a long-term horizon. Research indicates that 'short-term' financial cycles may last for up to nine years (Hilbers et al. 2005), whilst 'medium-term' cycles may last anything up to 30 years (Drehmann et al. 2012). Naturally, deferral periods will assist in mitigating the effects of increased risk within a sector or institution, but it is clear that certain risks may take many years to manifest - certainly over timeframes longer than three years. Furthermore, there are inconsistencies in relation to whether a deferred equity plan, which does not cover a significant period of time, would increase a focus on the long-term, because there would remain a large period of time under which the incentives of senior executives would be the same as with a non-deferred plan (Spindler 2011).

Claw-back policies - which in the main have similar aims to mandating deferral - are also recommended in Iceland and the major Western financial centers. However, there are significant practical constraints imposed on retrieving remuneration that has already been awarded as an ex-post adjustment, particularly if these payments were made a significant time previously. Moreover, there is nascent evidence that the use of claw-back may encourage earnings manipulation; specifically, there is a correlation between clawback and an increase in 'real transactions management, ('RTM') which is a method of artificially boosting earnings. RTM boosts profits over the short-term, but after three years, the pattern reverses (Chan et al. 2015). We therefore contend that the many drawbacks of enforcing and implementing claw-back could be solved by forcing banks to defer variable compensation for much longer periods than currently mandated.

On this basis, we recommend that mandatory deferral periods mirroring those in the UK are much more appropriate for large banks. Seven-to-ten years has been selected because this strikes the appropriate balance between reigning in risk and allowing the financial cycle to 'smooth out' equity and asset prices and financial performance measurements (Cullen 2014). Whilst investment risks may take years to emerge, arguably most would become apparent within a time-frame of a decade or so. This lengthened time horizon therefore ought to capture tail-risk and prevent managers from profiting from the effects of a major credit boom, or from short-term accounting manipulation. It would also reduce the need for claw-back which, as we have noted, poses many practical difficulties if invoked. 


\subsection{Reducing reliance on equity-based pay}

In contrast to the so-called 'best-practice' approach to aligning pay-with-performance by awarding senior employees with equity-based awards enshrined in both current UK and EU regulations, we argue that deferred payments ought to be comprised of instruments which incentivize longer-term investment horizons, rather than the tried, tested and failed approach of virtual wholesale reliance on equity-based payments. Theory suggests, of course, that where agents derive much of their utility from financial compensation, the most efficient way to contract is to provide them with incentives to align their financial interests with those of their principals. There is a well-developed literature which demonstrates a strong positive link between the use of performance-related pay and shareholder returns (Jensen \& Murphy 1990; Boschen \& Smith 1995), and over the past two decades, the use of equity-based compensation was encouraged - including at large banks - across Western jurisdictions by regulators and even legislation.

However, as we have noted previously in the case of Iceland, relying on equity payments presents many difficulties, particularly the manipulation of equity. The banking sector has witnessed extreme forms of RWO, (risk weight optimization) and use of SPVs (special purpose vehicles), designed to circumvent capital regulation. Moreover, perhaps more dangerously, as we have already noted, equity payments incentivize leverage and higher-risk taking. Balachandran et al. (2010) find that approximately $60 \%$ of the compensation of named executive officers at US banks comprised equity-based pay. Whilst there is some comfort to be had from the increased capital requirements of Basel III, and the strengthening and/or introduction of binding leverage ratios across certain jurisdictions, increasing equity requirements may simply not prove sufficient in the presence of high complexity, extreme opaqueness of ownership structures and crossborder financial transactions. In this environment, the temptation and the opportunity to misreport on equity levels to capture compensation (or other incentives such as job retention) remain strong.

We therefore contend that equity-related incentives ought to comprise no more than $33 \%$ of the total proportion of incentive compensation. There are undoubted benefits in seeking to align the interests of agents with their principals, but the large-scale reliance on equity-based pay - especially in combination with the use of performance targets such as $\mathrm{RoE}$ - arguably poses incentives to manipulate equity levels and/or increase leverage.

\subsection{Moving away from RoE as a measure of performance}

As highlighted by UK authorities, RoE constitutes a highly imperfect measure of corporate performance and may incentivize excessive risk. We therefore argue that EU banks are forced to move away from using equity-linked metrics with which to judge performance. Along with the suggestion in the UK Rem-Code that risk-adjusted profits be used as the basis for bonus decisions, rather than RoE or TSR (total shareholder return), there have been several recommendations - from scholars in particular - which are designed to mitigate the wholesale reliance on equity prices which is currently exhib- 
ited in the calculation of variable compensation. On this theme, there have been several suggested mechanisms.

In examining recent regulatory guidance, the most preferable solution appears to have been to require a proportion of variable compensation to be linked to either RoRWA (the current position in relation to compensation at Icelandic banks) or RoA. The use of either RoRWA or RoA reduces the incentives for senior executives to concentrate not simply on the returns generated for shareholders, but on the returns generated by assets under management (Haldane 2012), and each provides a snapshot of the efficiency of the use of firm capital to generate returns (ie. whether leverage is being used optimally). On this basis, a focus on RoRWA or RoA in determining compensation, rather than on RoE would have resulted in much lower compensation for senior executives at financial institutions prior to 2008, and arguably less risk. Moreover, a focus on either RoRWA or RoA would preserve some degree of market discipline, because the RoRWA/RoA of corporations - even banks who hold immense asset volumes - are relatively easy to measure and report on.

In terms of the appropriate measure of risk to use in these calculations, we submit that RoA is on balance to be preferred. Embedding a focus on RoRWA would arguably provide further incentives for bankers to engage in forms of risk-weighting manipulation; unlike RoRWA, RoA - much like the leverage ratio in the context of capital requirements regulation - strips out the effects of risk-weighting of assets in banks' portfolios, thus avoiding the dangers of risk-weight optimization (RWO) which, despite contributing significantly to the undercapitalization of the banking system prior to the GFC, continues to be employed across today (Blundell-Wignall \& Roulet 2013). In benign economic conditions most assets pay off and banks book capital gains based on (today's) high asset prices. Of course, this feeds into bank risk models and will tend to reduce the overall reported risk of a banks' asset portfolio. These dangers would arguably be more potent under the RoRWA incentive system, because additional incentives for bankers to manipulate risk-weights will arise. In contrast, a compensation system based (to some degree) on RoA - which is based on aggregate asset returns - regardless of the portfolio composition, would not carry the same incentives to engage in RWO or asset substitution (although of course, the same dangers we highlight above - those of increased asset turnover, higher average asset risk and increased use of securitization would remain).

It must be conceded that a migration to these measures may also create (some) distortions, which is why the use of a blend of metrics in the pay totality calculation is to be preferred. Where compensation is deferred, and linked to a firm's long-run stock price or financial returns, payouts vary with the riskiness of firm assets, which means that the optimal way for bankers to maintain high levels of pay becomes targeting increased levels of asset risk, rather than manipulation of the capital structure of the firm (Chason 2013). Indeed, RoRWA/RoA incentives are positively related to risk levels and, moreover, very risky firms are characterized by higher ratios of asset turnover (Cheng et al. 2013). On this basis, if banks begin to switch to compensation plans which explicitly 
target RoRWA/RoA, the portfolio of assets held by financial institutions may become riskier, or they may engage in greater levels of asset substitution, making them harder to monitor. This may become more potent on the upward curve of the credit cycle because as asset values increase, assets become more profitable, and collateral constraints are relaxed (Minsky 1986) or sophisticated bankers/lawyers find ways to stretch collateral to use for further asset purchases (Geanakoplos \& Zame 2010). Incentivizing a focus on either RoRWA/RoA also implicitly encourages securitization of assets. Whilst securitization as a means of risk transfer and/or diversification is not, in of itself, an unwelcome development, it increases a bank's RoRWA/RoA by shrinking its balance sheet which, of course, facilitates greater leverage. Embedding a focus on RoRWA/ RoA in compensation contracts may therefore provide unwelcome additional incentives to securitize which have little to do with the efficient allocation of resources and risk, especially as the underpricing of risk in the securitization market (albeit to achieve capital relief) is regarded as a key driver of the GFC (Brunnermeier \& Pedersen 2009; Diamond \& Rajan 2009).

For these reasons, we would recommend that at least $35 \%$ of variable compensation at banks should be determined by reference to RoA, which in our view provides an appropriate balance between the various forms of incentive compensation without exposing banks unduly to the increase in asset risk that a singular focus on either RoE or RoA as a performance-determining metrics may provide.

\subsection{Constructive ambiguity}

We are of the view that EU regulators ought to follow the Icelandic example, and introduce so-called 'constructive ambiguity' into compensation plans at banks, as a rational and disciplining force on incentives to game compensation systems. The term 'constructive ambiguity' in the context of financial markets is normally used to discuss the lack of specificity given by a Lender of Last Resort regarding the scope and extent of its bailout policies, with the aim of instilling market discipline and encourage private sector solutions in preventing excessive risk which may lead to the need for public rescue. In the case of compensation, regulators may use regular reviews of pay plans and practices to prevent bankers from consistently manipulating those plans to their advantage, which is achievable thanks to their superior knowledge of the environment. In fact, instilling any ambiguity about what metrics will decide bonus pay in the near future may be constructive by preventing gaming, a commonly identified weakness of incentive pay, and result in superior efficiency in compensation (Ederer et al. 2014).

\subsection{Capping variable pay at $50 \%$}

Finally, we recommend that the EU mandatory cap on variable pay across banking institutions be maintained. This has been perhaps the most contentious regulatory proposal in relation to bankers' pay to arise from the GFC in Europe. We argue that the default position that variable compensation must be capped to the same level as fixed compensation $(1: 1-$ in other words, $50 \%)$ ought to be enforced absolutely, with no power 


\section{STJÓRNMÁL \& \\ STJÓRNSÝSLA}

for shareholders to ratify higher variable compensation, as is currently permitted under CRD IV. We believe that the European cap (as opposed to the Icelandic cap of 25\%) strikes the right balance between prudence and excess, and is unlikely to damage the reputation or competitiveness of the European financial markets, despite some trenchant views expressed to the contrary. Of course, many have argued that an unintended consequence of the cap on variable pay will be an increase in base salaries at financial institutions (Murphy 2013) or, indeed the circumvention of rules on variable pay (for example, through the re-categorization of forms of compensation as 'allowances'). Each of these developments will, to some degree, break the supposed link between pay and performance at European financial institutions. Yet, what is indisputable is that little or no empirical links can be found between a fixed salary model and misreporting or excessive risk-taking. Notwithstanding the deep-seated problems with corporate governance at banks, shareholders retain the power to reign in boards whose fixed salaries they deem 'excessive' and if they are of the view that senior bankers are shirking and/or are simply not 'worth' the salaries they are being paid, they can use their voting powers to object to compensation packages (Johnston 2014). Very few other industries tolerate such large discrepancies between fixed and variable pay and, considering the potentially toxic combinations of the capital and funding structures of banks, the financial stability risks posed by large institutions, and the high-powered incentives present particularly at senior levels, limiting variable compensation in this way is arguably justified.

\section{Conclusion}

In this article, we have argued that the program of reform to senior bankers' compensation in the EU is incomplete. In doing so, we have analyzed the law and finance literature on efficient compensation incentives, as well as drawing on some of the legislative reforms in the EU, UK and Iceland to provide comparative perspectives. We performed a brief empirical analysis of the events which led to the Icelandic bank collapses during the GFC, which exhibited many of the incentive issues associated with the failure of large Western financial institutions, as well surveying elements of the post-GFC reforms to compensation regulation in the EU, the UK and Iceland. Using the case of Iceland as a benchmark (although not a paragon in this regard), as well as observations on similar trends in the UK and EU, we made some recommendations for further reforms to compensation packages which we hope will guard against the danger that compensation incentives induce excessive risk-taking in the banking sector going forward.

On this basis, we hope that the recommendations made to address some of the shortcomings of current and proposed reforms to executive pay at banks which may not prove sufficient to curb excessive risk-taking and that, indeed, many of the more 'tried and trusted' reforms, such as increasing equity incentives in pay packages, are likely to have perverse consequences from a financial stability perspective. We further hope that these recommendations address worries about the potential complexity of future compensation packages by setting clear and unambiguous bright-line rules to govern the composition of bankers' pay. In so doing, we also hope to have combined the best 
of all possible solutions into workable and efficient solutions to the issue of executive compensation at banks, from the standpoint of moderating excessive risk, and reducing potential costs to society at large.

\section{References}

Aboody, D. and Kasznik, R. (2000). "CEO stock option awards and the timing of corporate voluntary disclosures", Journal of Accounting and Economics 29, 73-100.

Akerlof, G. and Romer J. (1993). "Looting: The Economic Underworld of Bankruptcy for Profit", Brookings Papers on Economic Activity, 2, 1-73.

Akerlof, G. and Shiller R. (2015). Phising for Phools: The Economics of Manipulation \& Deception, New Jersey: Princeton University Press.

Armstrong, C.S. and Vashishtha, R. (2012). "Executive Stock Options, Differential Risk-taking Incentives, and Firm Value", Journal of Financial Economics 40, 70-88.

Avgouleas, E. and Cullen, J. (2015). "Excessive Leverage and Bankers’ Pay: Governance and Financial Stability Costs of a Symbiotic Relationship", Columbia Journal of European Law 21(1), 1-46.

Avgouleas, E. and Cullen, J. (2014). "Market Discipline and EU Corporate Governance Reform in the Banking Sector: Merits, Fallacies, and Cognitive Boundaries", Journal of Law and Society 41(1), 28-50.

Balachandran, S., Kogut B., and Harnal, H. (2010). "The Probability of Default, Excessive Risk, and Executive Compensation: A Study of Financial Services Firms from 1995 to 2008”, Columbia Business School Research Paper.

Bank of England (2015). Strengthening Individual Accountability in Banking and Insurance, Policy Statement, PS3/15.

Bebchuk, L.A. and Fried, J.M. (2010). "How to Tie Equity Compensation to Long-Term Results", Journal of Applied Corporate Finance 22(1), 99-106.

Berger, P., Ofek, E., and Yermack, D. (1997). "Managerial entrenchment and capital structure decisions", Journal of Finance 52, 1411-1438.

Bergstresser D. and Philippon T. (2006). "CEO incentives and earnings management", Journal of Financial Economics 80, 511-529.

Bhagat, S. and Romano R. (2009). "Reforming Executive Compensation", Yale Journal on Regulation 26, 359.

Bhattacharya, S., Goodhart, C., Tsomocos, D., and Vardoulakis, A. (2011). "Minsky's Financial Instability Hypothesis and the Leverage Cycle", LSE Financial Markets Group Special Paper 202/2011.

Bologna, P., Caccavaio M., and Miglietta A. (2014) "EU Bank Deleveraging", Bank of Italy Occasional Papers.

Bolton, P., Scheinkman J., and Xiong W. (2005) "Pay for Short-Term Performance: Executive Compensation in Speculative Markets", ECGI Finance Working Paper No. 79/2005.

Borio C. and Lowe, P. (2002). "Asset prices, financial and monetary stability: exploring the nexus", BIS Working Paper No. 114.

Boschen, J.F. and Smith, KJ. (1995) "You Can Pay Me Now and You Can Pay Me Later: The Dynamic Response of Executive Compensation to Firm Performance", Journal of Business 68, 577.

Brunnermeier, M.K. and Pedersen, L. (2009). "Market Liquidity and Funding Liquidity", Review of Financial Studies 22, 2201-2238.

Burns, N. and Kedia, S. (2006). "The Impact of Performance-Based Compensation on Misreporting", Journal of Financial Economics 79, 35.

Chan, L.H., Chen, K.C.W., Chen, T.Y., and Yu, Y. (2015). "Substitution between Real and AccrualsBased Earnings Management after Voluntary Adoption of Compensation Clawback Provisions", Accounting Review 90, 147-174.

Chason, E.D. (2013). “The Uneasy Case for Deferring Banker Pay”, Louisiana Law Review 73, 923. 


\section{STJÓRNMÁL \& \\ STJÓRNSÝSLA}

Chen, C.R., Steiner T.L., and Whyte A.M. (2006). "Does Stock-Option-Based Compensation Induce Risk-Taking? An Analysis of the Banking Industry", Journal of Banking and Finance 30, 915.

Cheng, I.H., Hong H., and Scheinkman, J.A. (2013). "Yesterday's Heroes: Compensation and Risk at Financial Firms", NBER Working Paper No.16176.

Cheng Q. and Warfield, T.B. (2005). "Equity Incentives and Earnings Management", Accounting Review $80,441$.

Chesney, M., Stromberg, J., and Wagner, A.F. (2011). "Risk-taking Incentives, Governance, and Losses in the Financial Crisis", University of Zurich Swiss Finance Institute Working Paper No. 10-18.

Clementi, G.L., Colley, T.F., Richardson M., and Walter I. (2009). "Rethinking Compensation at Financial Firms", in V.V. Acharya and M. Richardson (eds.), Restoring Financial Stability: How To Repair A Failed System. New York: John Wiley \& Sons.

Cullen, J. (2014). Executive Compensation in Imperfect Financial Markets, Cheltenham: Edward Elgar Publishing.

De Larosiere Group (2009). The High Level Group On Financial Supervision in the EU.

Detken, C. and Smets, F. (2004). "Asset Price Booms and Monetary Policy", ECB Working Paper No. 364.

Diamond, D.W. and Rajan, R. (2009). "The Credit Crisis: Conjectures about Causes and Remedies", NBER Working Paper No. 14739.

Drehmann, M., Borio, C., Gambacorta, L. Jiménez, G. and Trucharte, C. (2010). "Countercyclical Capital Buffers: Exploring Options", BIS Working Paper No. 317.

Ederer, F., Holden, R., and Meyer, M. (2014). "Gaming and Strategic Opacity in Incentive Provision", Cowles Foundation Discussion Papers 1935.

Efendi, J., Srivastava, A., and Swanson E.P. (2007). "Why Do Corporate Managers Misstate Financial Statements? The Role of Option Compensation and Other Factors", Journal of Financial Economics $85,667$.

Fahlenbrach, R. and Stulz, R.M. (2011). "Bank CEO incentives and the credit crisis", Journal of Financial Economics 99, 11-26.

Financial Services Authority (2009). The Turner Review: A Regulatory Response to the Global Financial Crisis.

(2011) The Failure of the Royal Bank of Scotland.

Flannery, M.J. (2010). "Iceland's Failed Banks: A Post Mortem”, Special Investigation Commission Report.

Fostel, A. and Geanakoplos, J. (2013). "Reviewing the Leverage Cycle", Cowles Foundation Discussion Paper No. 1918.

Frydman, C. and Jenter, D. (2010). "CEO Compensation", Annual Review of Financial Economics 2, 75-102.

Geanakoplos, J. (2010). "Solving the Present Crisis and Managing the Leverage Cycle", FRB New York Economic Policy Review 101.

Geanakoplos, J. and Zame, W.R. (2010). "Collateralized Security Markets”, Levine Working Paper.

Haldane, A.G. (2011). "Control rights (and wrongs)", speech given at the Wincott Annual Memorial Lecture, 24 October.

Haldane, A.G, Brennan S., and Madouros, V. (2010). "The Contribution of the Financial Sector: Miracle or Mirage?”, in Turner et al, The Future of Finance, London: London School of Economics.

Healy P.M. (1985). "The Effect of Bonus Schemes on Accounting Decisions" Journal of Accounting and Economics 7, 85-107.

Hermalin, B.E. (2005). "Trends in Corporate Governance”, Journal of Finance 60, 2351-84.

Hilbers, P., Otker-Robe, I., Pazarbasioglu, C., and Johnsen, G. (2005). "Assessing and Managing Rapid Credit Growth and the Role of Supervisory and Prudential Policies", IMF Working Paper No. 05/151.

Holmström, B. (1979). "Moral Hazard and Observability", Bell Journal of Economics 10, 74-91.

Holmström, B. and Kaplan, S. (2001). "Corporate Governance and Merger Activity in the United States: Making Sense of the 1980s and 1990s", Journal of Economic Perspectives 15, 121-144.

Holthausen, R.W., Larcker, D.F., and Sloan, R.G. (1995). "Annual Bonus Schemes and the Manipulation of Earnings", Journal of Accounting and Economics 19, $29-74$. 
Jensen, M.C. and Murphy K.J. (1990). "Performance Pay and Top-Management Incentives", Journal of Political Economy 98, 225.

Johnsen, G., (2014). Bringing Down the Banking System: Lessons from Iceland. New York: Palgrave-Macmillan. Johnson, S.A., Ryan, H.E., and Tian Y.S. (2009). "Managerial Incentives and Corporate Fraud: The Sources of Incentives Matter", Oxford Review of Finance 13, 115.

Johnston, A. (2014). "Preventing the Next Financial Crisis: Regulating Bankers' Pay in Europe", Journal of Law and Society 41(1), 6-27.

Minsky, H.P. (1986). Stabilizing an Unstable Economy. New York: McGraw-Hill.

Modigliani, F. and Miller, M.H. (1958). "The Cost of Capital, Corporate Finance and the Theory of Investment", American Economic Review 48, 261.

Murphy, K.J. (2013). "Regulating Banking Bonuses in the European Union: A Case Study in Unintended Consequences", European Financial Management 19(4), 631-657.

Palia, D. and Porter, R. (2004). "The Impact of Capital Requirements and Managerial Compensation on Bank Charter Value", Review of Quantitative Finance and Accounting 23, 191-206.

Peng, L. and Roell, A. (2008). "Executive Pay and Shareholder Litigation", Review of Finance 12, 141-84.

Special Investigation Commission (2010). Background and Causes of the Collapse of the Icelandic banks in 2008 and Related Events, (vol. 2, 3, and 7). P.Hreinsson, S. Benediktsdottir, and T. Gunnarsson (eds.), Reykjavik.

Spindler, J.C. (2011). "Mandatory Long-Term Compensation in the Banking System - and Beyond?", Cato Institute Regulation Paper.

Talley, E.L. and Johnsen, G (2004). "Corporate Governance, Executive Compensation and Securities Litigation”, USC Law School, Olin Research Paper No. 04-7.

UK Parliamentary Commission (2013). Report of the Parliamentary Commission on Banking Standards, Changing Banking For Good: Vol. 1, HL 27-I; HC 175-I.

World Bank Group (2009). The Leverage Ratio: A New Binding Limit on Banks.

Yermack, D. (1997). "Good Timing: CEO Stock Option Awards and Company News Announcements", Journal of Finance 52, 449. 